\title{
Role of libraries in Pharmacy Education and Perceptions of library Professional's about their job
}

\author{
Irudayam Jayaraman ${ }^{1 *}$, Mottaiachettiar Tamizhchelvan ${ }^{2}$, Michael Antony Samy Amutha Gnana Arasi $^{3}$ \\ ${ }^{1}$ Department of Library, Anna University, Regional Centre, Coimbatore, 641047,TN,INDIA. \\ ${ }^{2}$ Department of Library, Gandhigram Rural Institute, Deemed University, Dindigul, 625302,TN, INDIA. \\ ${ }^{3}$ Department of Pharmaceutics, College of Pharmacy, Sri Ramakrishna Institute of Paramedical Sciences, Coimbatore, 641044,TN, \\ INDIA.
}

\begin{abstract}
Introduction: In pharmacy education, library use do appear independent contributions to desirable outcomes of the institution. Librarians' role is also important to make students information literate. Objective: This objective of this study to know about the role of libraries and library professional's experience in pharmacy colleges. Materials and Methods: The data represent responses from 44 library professionals' during the period 2013-2014 to the questionnaire. To explore role of libraries in pharmacy colleges, current status on collections and digital library facilities are discussed and to know the perceptions of library professionals', their job satisfaction level is analyzed. Results: Pharmacy colleges have numerous seminar materials, sufficient journals, articles and conference papers. Almost all the pharmacy college libraries perform the data entry, circulation services. Some colleges maintain reports and database services $(73.5 \%)$. Digital library initiative started in many colleges $(75.2 \%)$. Very few colleges do have connecting networks like UGC Inflibnet (1.7\%), Delnet (2.2\%). No pharmacy college has got Current Awareness Services (CAS)/Selective Designated Information (SDI) services and computerized bibliographic service. The library professionals' of all designations do have high level of job satisfaction. Conclusion: Pharmacy colleges of this study have enough conventional collections, but latest modern technology like connecting network, security measures are to be developed. Since pharmacy graduates get involved in clinical aspects, drug information resources, learning tools and materials and databases for clinical aspects are also required in library. All library professionals' in this study are satisfied with their collection and resources available in the library and nature of their work.
\end{abstract}

Key words: Collections and facilities in library, Database, Drug information source, Library professionals, Pharmacy education, Role of Library.

\section{INTRODUCTION}

Education is the act or process which imparts or acquires general knowledge, develops the powers of reasoning and judgment, and trains the individual for mature life. It is the result produced by instruction, training or study. ${ }^{1}$ Pharmacist today face challenges to ensure access and rational use of efficacious, quality, and safe medicines and health technologies; Strengthening and harmonization of pharmacy education is essential for the development of basic medical and pharma- ceutical sciences to serve the society. Libraries are pivotal in supporting and achieving the mission of higher education in today's information world. Faculty, students and research scholars always depend on libraries and librarians. Librarians generously share their knowledge with them. ${ }^{2}$

\section{College Libraries}

Services rendered by the college libraries can be categorized as reader services and auxil-
Submission Date : 07-02-2015

Revision Date :02-04-2015 Accepted Date :23-04-2015

DOI: $10.5530 / \mathrm{ijper} .49 .4 .5$ Correspondence Address Mr. Jayaraman. I Assistant Librarian, Anna University, Regional Centre,

Jothipuram (PO), Veerapandi Pirivu, Coimbatore, India-641047.

Email:ijayaraman71@gmail. com

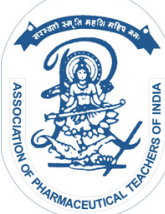

www.ijper.org 


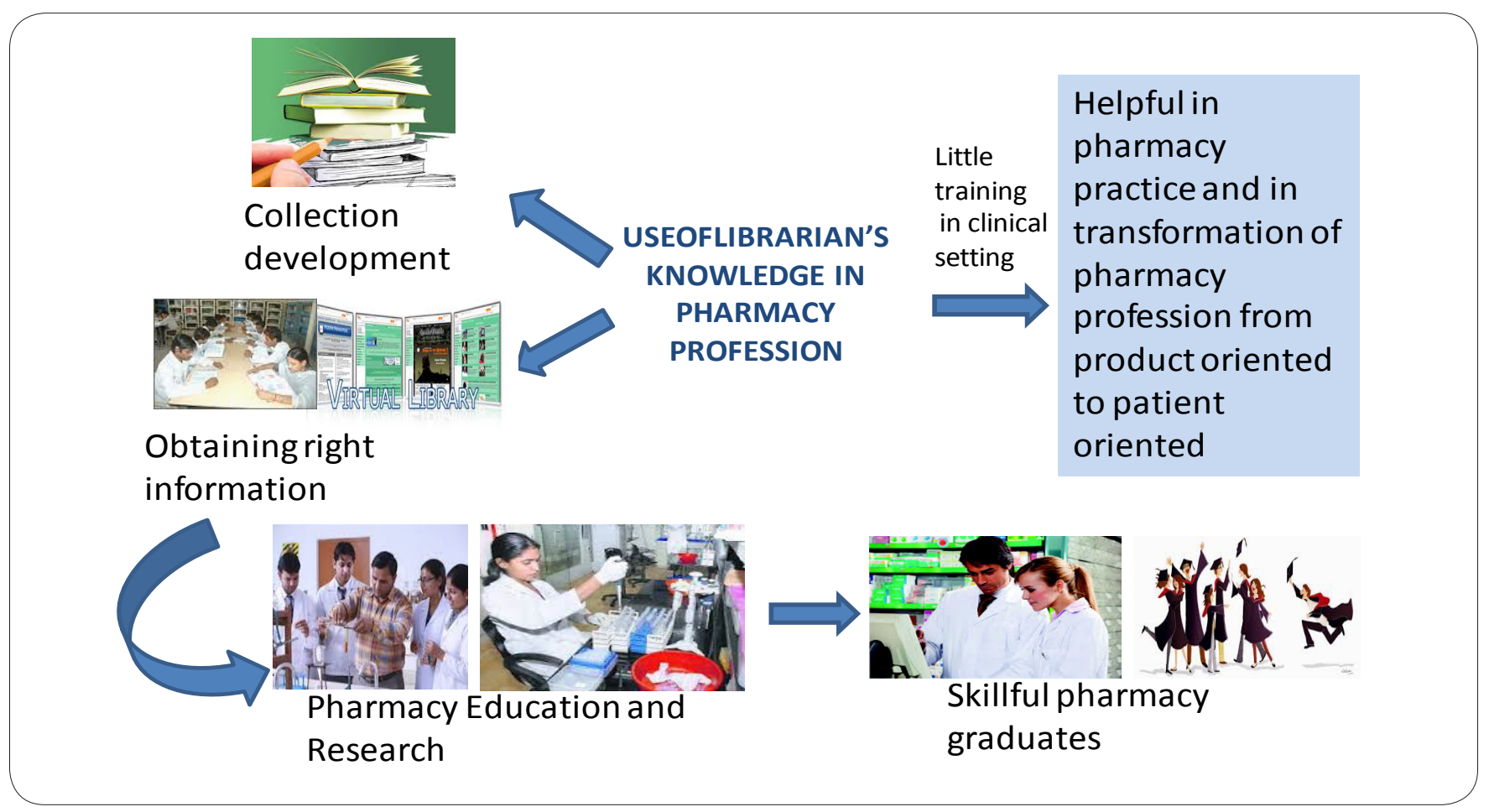

\section{Pictorial Abstract}

iary services. Reader service include services related to reference collection, to satisfy the user by serving with appropriate information, to advice the students about what to read, tracing periodicals and books, to assist in formulating bibliographies, to organize exhibition, to arrange lectures and to play a role of information mediator. The auxiliary services include documentation services like current awareness list, selective dissemination of information, indexing and abstracting services, translation services, reprographic services, micro recording, microfilm, micro card, microfiche, filmstrip, to work as a documentation centers and to work as a formation centers.

In $21^{\text {st }}$ century, academic libraries have undergone newer developments to support a series of new scenarios. ${ }^{3}$

- Scholarly communication and new publication and scenarios.

- Optimum use of digital resources.

- Handling heterogeneous student population.

- Managing high demand from users for traditional resources.

- Adapting to new modes of study, including ICTbased and distance learning.

- Adjusting with reduced human resources leading to enormous pressures on individual staff.

\section{Pharmacy education in India}

At present, more than 1500 institutions provide several pharmacy education programmes across the country. ${ }^{4}$ Nearly 100,000 students get enrolled into pharmacy colleges annually. High influx of students into pharmacy colleges is observed at an all time. The pharmacy degree programs offered in India include: Diploma in Pharmacy (D.Pharm), Bachelor of Pharmacy (B.Pharm), Master of Pharmacy (M.Pharm), Master of science in Pharmacy [Ms (Pharm)], Master of Technology in Pharmacy [M.Tech (Pharm)], Doctor of Pharmacy (Pharm D), Pharm D Post baccalaureate and Doctor of Philosophy in Pharmacy (Ph.D) ${ }^{5}$. Integrated courses such as B.Pharm + MBA or M.Pharm + MBA are available in few colleges. Pharmacy educational institutions in India provide students adequate knowledge and necessary skills to practice the profession of pharmacy. Pharmacy institutions provide complete knowledge of formulation, synthesis and analysis of medicinal agents, their mode and mechanism of action, adverse drug reactions, drug interactions, patient counseling techniques and adequate technical information to be exchanged with the physician and other health professionals. Concepts of community pharmacy, quality assuarance, and regulatory issues are also taught in pharmacy colleges. Pharmacy institutions focus on training student in producing medicines, ready to use in the market and to train them to act as interface between the physician and patients for achieving better health of community.

\section{Pharmacy education in Tamil Nadu}

Now there are around 64 institutions offering pharmacy courses at bachelor level. Most of the colleges have started offering post-graduate courses. Many teachers attached to the institutions have also completed Ph.D. in pharmacy. There has been a substantial quantitative 


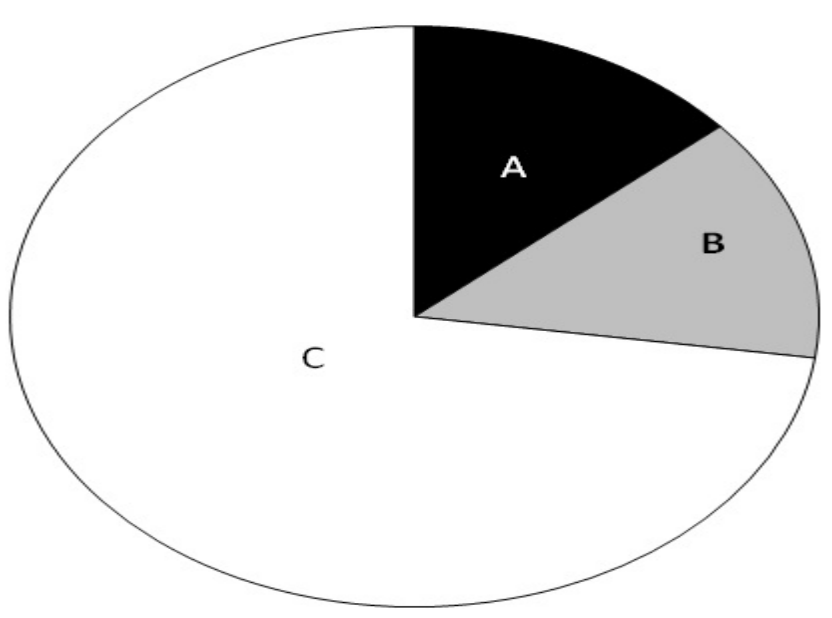

Figure 1: Designation of library professional's of Pharmacy colleges

Values are frequency percentage.

A-Assistant Librarian (13.64\%) ; B-Deputy Librarian (13.64\%) ; C-Librarian (72.73\%)

growth of pharmacy institution in the state towards the promotion and development pharmaceutical field. Since 2007, focusing more on clinical aspects, new courses Pharm D (6 years) and Pharm D Post Baccalaureate

(3 years after B.Pharm) have been started.

\section{Librarian's role in the learning and teaching context}

- Working together with faculty and other specialists for delivery of information and instruction;

- Designing instructional programs for information access;

- Teaching students and faculty how to access information, whatever its format or location and how to evaluate what they find;

- Serving as consultants on information resources, issues, and problems;

- Developing and implementing information policy; Creating information access tools;

- Selecting, organizing, and preserving information in all formats; serving as leaders and facilitators by introducing information technologies and ensuring their effective use. ${ }^{6,7}$

Nowadays due to the unlimited access to information via internet, need for actual library and physical material are less. Digital libraries provide many facilities to education in general education and higher education in particular. $^{8}$ In the past, information about what was worth reading and collecting could be obtained from knowledge gatekeepers (journal editors and librarians). Today students make their own judgment without assistance. Challenging role of librarians in this situation is to inform the users that not everything available electronically is valid and reliable. ${ }^{9}$ Library collection must include resources like

\begin{tabular}{|c|c|c|c|}
\hline \multicolumn{5}{|c|}{ Table 1: Collections of pharmacy college libraries } \\
\hline Colletions & Mean & Sum & Maximum \\
\hline Books & 25246.02 & 1110825 & 160000 \\
\hline Current periodical & 120.61 & 5307 & 542 \\
\hline Back volumes & 1562.36 & 68744 & 6000 \\
\hline Online journals & 1002.45 & 44108 & 33000 \\
\hline Projects & 703.55 & 30956 & 5000 \\
\hline Electronic projects-UG & 104.55 & 4600 & 2000 \\
\hline Electronic projects-PG & 27.82 & 1224 & 584 \\
\hline CD & 2166.66 & 95333 & 7300 \\
\hline Floppy & 50.07 & 2203 & 1000 \\
\hline Video tape & 43.84 & 1929 & 200 \\
\hline Palm leaves & .00 & 0 & 0 \\
\hline Micro fiche & .00 & 0 & 0 \\
\hline Thesis & 157.64 & 6936 & 3026 \\
\hline Directory & 31.39 & 1381 & 203 \\
\hline Annual reports & 50.02 & 2201 & 742 \\
\hline Manuals & 22.75 & 1001 & 500 \\
\hline Others & 1.14 & 50 & 50 \\
\hline
\end{tabular}

(Source: Original)

print, non-print, electronic resources, digital resources. ${ }^{10}$ The libraries in pharmacy colleges should have enough collections and services facilitate the rapid information retrieval focused to the needs of the user. This article gives an overview about the information sources and services of college libraries and experiences of librarians work in pharmacy colleges of Tamil Nadu.

\section{MATERIAL AND METHODS}

The data collected through questionnaire distributed among library professional's during the period 20132014. The responses collected from 44 filled in questionnaire. Library professional's filled the information regarding the collections and resources available in library and their experience in library is recorded using 5 point Likert scale as strongly agree, agree, undecided, disagree, strongly disagree and the score of the response are calculated by the score ranges between 5 and 1 , say score 5 given for most favorable response (strongly agree) and score 1 for least favorable response (strongly disagree). ${ }^{11}$

\section{Data analysis}

On the basis of the responses in received questionnaires, the opinion of library professionals' on several library resources services were analyzed using SPSS software.

\section{Statistical methods}

Basic descriptive staististics include mean, standard deviation, maximum and minimum. Kruskal Wallis test 


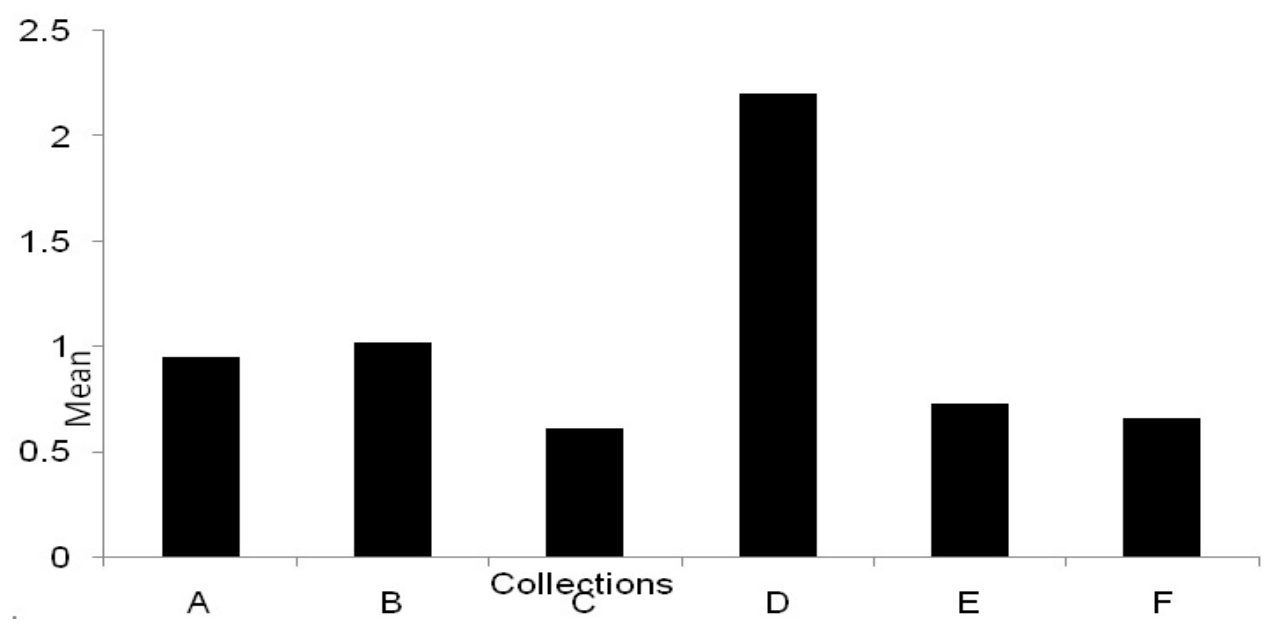

Figure 2: Conventional collections of pharmacy college libraries

Values are mean of conventional collections in pharmacy college libraries.

A-Books; B-Journals; C-Articles ; D-Seminar materials ; E-Conference paper ; F-Others

\begin{tabular}{|c|c|}
\hline $\begin{array}{c}\text { Table 2: Information technology application in phar- } \\
\text { macy college libraries }\end{array}$ \\
\hline $\begin{array}{c}\text { INFORMATION TECHNOLOGY } \\
\text { APPLICATIONS }\end{array}$ & PERCENT OF CASES \\
\hline Data entry & $100.0 \%$ \\
\hline Circulation & $98.3 \%$ \\
\hline Report & $70.9 \%$ \\
\hline Networked with other department & $20.6 \%$ \\
\hline Database services are available & $73.5 \%$ \\
\hline UGC/Inflibnet & $1.7 \%$ \\
\hline Delnet & $2.2 \%$ \\
\hline Others & $21.5 \%$ \\
\hline Digital library initiatives & $75.2 \%$ \\
\hline Computerized CAS/SDI service & $0 \%$ \\
\hline Computerized bibliographic & $0 \%$ \\
\hline services & $82.1 \%$ \\
\hline Internet services & $4.0 \%$ \\
\hline Others & \\
\hline
\end{tabular}

(Source: Original)

CAS-Current Awareness Services; SDI-Selective Designated Information services

is used to find the perceptions of library professional's based on the designation regarding collection and resource of Pharmacy colleges. The Kruskal-Wallis test is a rank-based nonparametric test that can be used to determine if there are statistically significant differences between two or more groups of an independent variable on a continuous or ordinal dependent variable. ${ }^{12}$ Here we used the different groups of different designation. After checking the significance we compare the mean of the descriptive statistics.

\section{RESULTS}

Designation of library professional in most of the pharmacy colleges is Librarian (72.73\%) and some colleges have Assistant Librarian (13.64\%) and Deputy Librarian (13.64\%). Library assistants help them in library services. The details are shown in Figure 1. Based on the responses filled by the library professionals' the present collections available in pharmacy college libraries include books journals, articles, seminar, conference materials, and other non print and digital materials. Palm leaves and microfiche are not available. Details are shown in Table 1. The mean of the conventional collection of libraries in pharmacy colleges is depicted in Figure 2. Mean of seminar material is 2.2 shows that pharmacy colleges have numerous seminar materials which would enable the students to know current aspects of the field. They have sufficient journals, articles and conference papers too.

Table 2 explains the available internet technology applications in pharmacy college libraries. Almost all the pharmacy college libraries perform the data entry, circulation services. Some colleges maintain reports and database services (73.5\%). Digital library initiative started in many colleges $(75.2 \%)$. Very few colleges do have connecting networks like UGC Inflibnet (1.7\%), Delnet $(2.2 \%)$. No college has got Current Awareness Services (CAS)/Selective Designated Information (SDI) services which would be very useful to know number of items available in various categories of collections in the library. A computerized bibliographic service is also available in none of the pharmacy college libraries.

To know the perceptions of library professionals' regarding collection and resource of pharmacy colleges the information of descriptive statistics and Kruskal Wallis test are used and data are given in Table 3 and 4.

Null Hypothesis (H1): There is no significant difference exists between library professional opinions based on designation. Since for all the questions, the $\mathrm{p}$ values in Table 2 are greater than the tabulated value (0.05), we 
Table 3: Descriptive Statistics on perceptions of library professionals' regarding collection and resource of Pharmacy college libraries

\begin{tabular}{|c|c|c|c|c|c|}
\hline $\begin{array}{c}\text { Acquisition } \\
\text { of collection } \\
\text { development }\end{array}$ & 44 & 4.23 & .721 & 1 & 5 \\
\hline $\begin{array}{c}\text { Adequate training } \\
\text { relating to my job }\end{array}$ & 44 & 3.62 & 1.213 & 1 & 5 \\
\hline $\begin{array}{c}\text { Modern technology } \\
\text { library }\end{array}$ & 44 & 3.86 & 1.123 & 1 & 5 \\
\hline $\begin{array}{c}\text { Comfortable using } \\
\text { online resources }\end{array}$ & 44 & 4.24 & .713 & 1 & 5 \\
\hline $\begin{array}{c}\text { Your work is not } \\
\text { secretarial service }\end{array}$ & 44 & 3.66 & .944 & 1 & 5 \\
\hline $\begin{array}{c}\text { Sufficient } \\
\text { manpower } \\
\text { available-technical }\end{array}$ & 44 & 3.46 & 1.243 & 1 & 5 \\
\hline $\begin{array}{c}\text { Sufficient } \\
\text { manpower } \\
\text { available-non- } \\
\text { technical }\end{array}$ & 44 & 3.33 & .814 & 1 & 5 \\
\hline
\end{tabular}

(Source: Original)

\begin{tabular}{|c|c|c|c|c|c|}
\hline \multirow[b]{2}{*}{ Questions } & \multirow[b]{2}{*}{ Designation } & \multirow[b]{2}{*}{$\mathbf{N}$} & \multirow[b]{2}{*}{ Mean Rank } & \multicolumn{2}{|c|}{ Test Statistic } \\
\hline & & & & Chi-Square & $\begin{array}{l}\text { Asymp. } \\
\text { Sig. }\end{array}$ \\
\hline \multirow{3}{*}{$\begin{array}{l}\text { Acquisition } \\
\text { of collection } \\
\text { development }\end{array}$} & Assistant Librarian & 6 & 152.22 & \multirow{3}{*}{.424} & \multirow{3}{*}{.809} \\
\hline & Deputy Librarian & 6 & 157.01 & & \\
\hline & Librarian & 32 & 149.59 & & \\
\hline \multirow{3}{*}{$\begin{array}{l}\text { Adequate } \\
\text { training relating } \\
\text { to my job }\end{array}$} & Assistant Librarian & 6 & 145.31 & \multirow{3}{*}{452} & \multirow{3}{*}{.798} \\
\hline & Deputy Librarian & 6 & 155.91 & & \\
\hline & Librarian & 32 & 151.61 & & \\
\hline \multirow{3}{*}{$\begin{array}{l}\text { Modern } \\
\text { technology } \\
\text { library }\end{array}$} & Assistant Librarian & 6 & 149.51 & \multirow{3}{*}{.796} & \multirow{3}{*}{672} \\
\hline & Deputy Librarian & 6 & 159.80 & & \\
\hline & Librarian & 32 & 149.37 & & \\
\hline \multirow{3}{*}{$\begin{array}{l}\text { Comfortable } \\
\text { using online } \\
\text { resources }\end{array}$} & Assistant Librarian & 6 & 162.57 & \multirow{3}{*}{1.142} & \multirow{3}{*}{.565} \\
\hline & Deputy Librarian & 6 & 149.98 & & \\
\hline & Librarian & 32 & 149.29 & & \\
\hline \multirow{3}{*}{$\begin{array}{c}\text { Your work is } \\
\text { not secretarial } \\
\text { service }\end{array}$} & Assistant Librarian & 6 & 145.57 & \multirow{3}{*}{1.321} & \multirow{3}{*}{.517} \\
\hline & Deputy Librarian & 6 & 161.89 & & \\
\hline & Librarian & 32 & 149.67 & & \\
\hline \multirow{3}{*}{$\begin{array}{l}\text { Sufficient } \\
\text { manpower- } \\
\text { technical }\end{array}$} & Assistant Librarian & 6 & 158.34 & \multirow{3}{*}{2.730} & \multirow{3}{*}{.255} \\
\hline & Deputy Librarian & 6 & 164.56 & & \\
\hline & Librarian & 32 & 145.74 & & \\
\hline \multirow{3}{*}{$\begin{array}{c}\text { Sufficient } \\
\text { manpower-non- } \\
\text { technical }\end{array}$} & Assistant Librarian & 6 & 158.40 & \multirow{3}{*}{3.348} & \multirow{3}{*}{.187} \\
\hline & Deputy Librarian & 6 & 163.35 & & \\
\hline & Librarian & 32 & 146.10 & & \\
\hline
\end{tabular}

(Source: Original) 


\section{Table 5: Cross tabulation of job satisfaction of library profes- sionals based on designation}

\begin{tabular}{|c|c|c|c|c|}
\hline \multicolumn{2}{|c|}{} & \multicolumn{3}{|c|}{ Job satisfaction classification } \\
\cline { 2 - 5 } & Low & High & Total \\
\hline \multirow{2}{*}{$\begin{array}{c}\text { Assistant } \\
\text { librarian }\end{array}$} & $\%$ within designation & $16.7 \%$ & $83.3 \%$ & $100.0 \%$ \\
\cline { 2 - 5 } & Count & 1 & 5 & 6 \\
\hline $\begin{array}{c}\text { Deputy } \\
\text { Librarian }\end{array}$ & $\%$ within designation & $16.7 \%$ & $83.3 \%$ & $100.0 \%$ \\
\cline { 2 - 5 } & Count & 4 & 28 & 32 \\
\hline \multirow{2}{*}{ Librarian } & $\%$ within designation & $1.3 \%$ & $87.5 \%$ & $100.0 \%$ \\
\hline \multirow{2}{*}{ Total } & Count & 5 & 39 & 44 \\
\cline { 2 - 5 } & $\%$ within designation & $11.4 \%$ & $88.6 \%$ & $100.0 \%$ \\
\hline
\end{tabular}

(Source: Original)

\begin{tabular}{|c|c|c|}
\hline Clinical Aspect & Preferred suggestion & Alternate Suggestion \\
\hline Adverse Effects & $\begin{array}{c}\text { AHFS Drug Information, Clinical } \\
\text { Key-Drugs, Drug Facts and } \\
\text { comparisons,LexiComp, MICROMEDEX }\end{array}$ & $\begin{array}{l}\text { DailyMed, PubMed (articles), } \\
\text { Manufacturer's Websites }\end{array}$ \\
\hline Bio equivalency & $\begin{array}{l}\text { Orange Book: Approved Drug Products } \\
\text { with Therapeutic Equivalence Evaluations }\end{array}$ & $\begin{array}{l}\text { Red Book (Part of Micromedex- } \\
\text { Only Accessible from BPL) }\end{array}$ \\
\hline Chemical Data & $\begin{array}{l}\text { ChemIDplus Lite, SciFinder Registration, } \\
\text { SciFinder On Campus Access, SciFinder } \\
\text { Off Campus Access }\end{array}$ & AHFS Drug Information \\
\hline Clinical Trials & ClinicalTrials.gov & CenterWatch \\
\hline $\begin{array}{l}\text { Comparative } \\
\text { Information }\end{array}$ & $\begin{array}{l}\text { Pharmacist's letter, AHFS Drug } \\
\text { Information, Drug Facts and Comparisons, } \\
\text { MICROMEDEX }\end{array}$ & PubMed \\
\hline Contraindications & $\begin{array}{c}\text { AHFS Drug Information, Drug Facts and } \\
\text { Comparisons, LexiComp, MICROMEDEX, } \\
\text { ClinicalKey-Drugs }\end{array}$ & $\begin{array}{l}\text { DailyMed, Manufacturers' Web } \\
\text { sites, PubMed }\end{array}$ \\
\hline Current News & $\begin{array}{l}\text { Medscape Pharmacists-News, } \\
\text { Pharmacist's Letter }\end{array}$ & $\begin{array}{c}\text { Drug Facts and Comparisons, Lexi- } \\
\text { Comp }\end{array}$ \\
\hline $\begin{array}{l}\text { Disease State } \\
\text { Information }\end{array}$ & $\begin{array}{c}\text { Up To Date, Access Pharmacy } \\
\text { (Pharmacotherapy: A Pathophysiologic } \\
\text { approach) Access Medicine, MedlinePlus } \\
\text { (for consumers) }\end{array}$ & Micromedex \\
\hline Dosage & $\begin{array}{l}\text { AHFS Drug Information, ClinicalKey-Drugs, } \\
\text { Drug Facts and Comparisons,LexiComp, } \\
\text { MICROMEDEX }\end{array}$ & $\begin{array}{l}\text { DailyMed, Manufacturers' Web } \\
\text { sites }\end{array}$ \\
\hline $\begin{array}{c}\text { Drug } \\
\text { Administration }\end{array}$ & $\begin{array}{l}\text { AHFS Drug Information, Drug Facts and } \\
\text { Comparisons, Lexi-comp, MICROMEDEX, } \\
\text { ClinicalKey-Drugs }\end{array}$ & Manufacturers' Web sites \\
\hline Drug Interactions & $\begin{array}{l}\text { Drug Facts and Comparisons, Lexi- } \\
\text { Comp, Natural Medicines Comprehensive } \\
\text { Database (drug-food, drug-herb, herb-herb } \\
\text { only), Natural Standard, Handbook on } \\
\text { Injectable Drugs }\end{array}$ & PubMed, MICROMEDEX \\
\hline Foreign Drugs & Martindale: The Complete Drug Reference & $\begin{array}{l}\text { MICROMEDEX, Lexi-Comp } \\
\text { (Select Indexes and Lexi-Drugs } \\
\text { International Online.) }\end{array}$ \\
\hline $\begin{array}{l}\text { Herbs and Natural } \\
\text { Products }\end{array}$ & $\begin{array}{c}\text { Natural Medicines Comprehensive } \\
\text { Database, Natural Standard,ConsumerLab }\end{array}$ & $\begin{array}{c}\text { Drug Facts and Comparisons, Lexi- } \\
\text { Comp }\end{array}$ \\
\hline
\end{tabular}

(Source: The Ohio state university libraries, http://library.osu.edu/find/subjects/pharmacy/drug-information-sources/) 


\begin{tabular}{|c|c|c|}
\hline Identification & $\begin{array}{l}\text { Drug Facts and Comparisons, } \\
\text { MICROMEDEX }\end{array}$ & $\begin{array}{l}\text { Lexi-Comp, Drugs.com(select } \\
\text { Pill Identifier) }\end{array}$ \\
\hline Immunization Schedules & $\begin{array}{l}\text { CDC Web Site, Epidemiology and } \\
\text { Prevention of Vaccine-Preventable } \\
\text { Diseases (The Pink Book) }\end{array}$ & Immunization Action Coalition \\
\hline $\begin{array}{c}\text { Investigational and New } \\
\text { Drugs }\end{array}$ & ClinicalTrials.gov & $\begin{array}{l}\text { Drugs.com-New Drug } \\
\text { Approvals, Drug Facts and } \\
\text { Comparisons,IPA,Pubmed }\end{array}$ \\
\hline Laboratory Values & $\begin{array}{l}\text { Drug Facts and Comparisons, Lexi- } \\
\text { Comp, Access Medicine }\end{array}$ & $\begin{array}{l}\text { Tietz Guide to Clinical Laboratory } \\
\text { Tests (RB38.2 C55 2006), }\end{array}$ \\
\hline Manufacturer's Information & DailyMed & Physicians' desk reference \\
\hline Over-the-Counter Drugs & $\begin{array}{l}\text { Drug Facts and Comparisons, Lexi- } \\
\text { Comp, MICROMEDEX }\end{array}$ & $\begin{array}{l}\text { Handbook of nonprescription drugs } \\
\text { : an interactive approach to self- } \\
\text { care }\end{array}$ \\
\hline $\begin{array}{l}\text { Patient Counseling and } \\
\text { Education }\end{array}$ & $\begin{array}{c}\text { OSU Wexner Medical Center Patient } \\
\text { Education Handouts, Pharmacist's } \\
\text { letter, (Pharmacist Resources } \rightarrow \text { Patient } \\
\text { Education Handouts) }\end{array}$ & $\begin{array}{l}\text { Micromedex, Lexicomp Patient } \\
\text { Education, Natural Medicines } \\
\text { Comprehensive Database }\end{array}$ \\
\hline Pharmacogenomics & $\begin{array}{c}\text { Lexi-Comp (Special section on } \\
\text { pharmacogenomics), FDA package } \\
\text { inserts }\end{array}$ & $\begin{array}{l}\text { Micromedex, Drug Facts and } \\
\text { Comparisons }\end{array}$ \\
\hline Pharmacokinetics & $\begin{array}{l}\text { AHFS Drug Information, Drug Facts } \\
\text { and comparisons, MICROMEDEX, } \\
\text { Access Pharmacy, Pharmacy Library }\end{array}$ & Manufacturers' Web sites,PubMed \\
\hline Pharmacology & $\begin{array}{l}\text { AHFS Drug Information, } \\
\text { MICROMEDEX, Access Pharmacy } \\
\text { (Goodman and Gilman's The } \\
\text { pharmacological basis of therapeutics) }\end{array}$ & $\begin{array}{c}\text { PubChem, Manufacturer's Web } \\
\text { sites }\end{array}$ \\
\hline Pregnancy/ Lactation & $\begin{array}{l}\text { Drugs in Pregnancy and Lactation: a } \\
\text { Reference Guide to Fetal and Neonatal } \\
\text { Risk, Lexi-omp }\end{array}$ & AHFS Drug Information, LactMed \\
\hline Prices & $\begin{array}{l}\text { Red Book - Part of Micromedex, this is } \\
\text { only accessible from BPL. }\end{array}$ & Drugstore.com \\
\hline Regulatory/Legal Information & Ohio State Board of Pharmacy & $\begin{array}{c}\text { Laws Enforced by the FDA and } \\
\text { Related Statutes }\end{array}$ \\
\hline Therapeutic Use (Off-label) & MICROMEDEX, IPA & PubMed, Pharmacist's Letter \\
\hline Therapeutic Use (Approved) & $\begin{array}{c}\text { Lexi-Comp, MICROMEDEX, AHFS } \\
\text { Drug Information, Drug Facts and } \\
\text { Comparisons, IPA }\end{array}$ & $\begin{array}{c}\text { FDA Web site, Manufacturers' Web } \\
\text { sites }\end{array}$ \\
\hline Toxicology/ Poisoning & MICROMEDEX & PubMed, Lexi-Comp \\
\hline
\end{tabular}

(Source: The Ohio state university libraries, http://library.osu.edu/find/subjects/pharmacy/drug-information-sources/)

accept the null hypothesis. There is no significant difference exists between opinions of library professional's based on their designation. We compare the mean of their descriptive statistics. Respondents ranked first that they are comfortable using online resources reveals that they can guide the students also for the effective utilization of modern digital and online resources. They are consulted for the collection and development is ranked second reveals that the librarians have adequate knowledge to serve the needs of the user with appropriate information. Modern technology library is ranked third by the respondents show that libraries in pharmacy col- leges are equipped with latest technologies, but still it has to be improved with digital library, connecting networks, more online databases, modern security measures like RFID (Radio frequency Identifier) and Automation of library. Library professional professional's s ranked last that they receive insufficient manpower including both technical as well as non technical.

Data in Table 5 shows that the library professional's of all designations do have high level of job satisfaction (above $83 \%$ ). It means they can work happily to serve the users' need as well as for the growth of the institution. 


\begin{tabular}{|c|c|}
\hline Free Evidence-Based Database & Subscription Evidence -Based Database \\
\hline Pubmed www.pubmed.com & ACP Medicine www.acpmedicine.com \\
\hline National Guideline Clearing house www.guideline.gov & Clinical Evidence http://clinical evidence.bm/com \\
\hline \multirow{4}{*}{ TRIP Database www.tripdatabase.com/index.html } & Clinical Pharmacology www.clinicalpharmacology.com \\
\hline & First Consult www.firstconsult.com \\
\hline & Essential Evidence Plus www.essentialevidenceplus.com \\
\hline & $\begin{array}{l}\text { Physician's information and education resources http://pier. } \\
\text { acponline.org }\end{array}$ \\
\hline
\end{tabular}

(Source: US Pharmacist, 2009)

\section{CURRENT SCENARIO}

\section{Database}

- Pharmacy colleges have some for accessing online journals. Databases available in pharmacy colleges are.

- Bentham-Bentham Science publishers publishes articles in 91 titles, which serve the information needs of the pharmaceutical, bio-medical and medical research fields. During 2008, they have launched "Bentham OPEN" with 200 plus peer-reviewed open access journals, this database provides full-text coverage of more than 29 journal title and back issues for specially pharmacy education knowledge. ${ }^{13}$

- Elsevier-Elsevier provides nearly 79 e-journals to pharmacy education, it deliver spans peer-reviewed articles, conferences and patents, and covers the latest research information such as patent records, approved drugs, events and other news with the pharmacy science which is essential to pharmacy researcher, students and faculty.

- Pharmacopeias-Pharmacy college libraries have various pharmacopeias contain drug information and they have updated editions too.

\section{Drug Information Resources}

As students in pharmacy colleges get engaged themselves with clinical aspects, library professionals' can suggest students to use online facilities to get drug information for various clinical regarding drug information sources. Table 6 and 7 list drug information resources. ${ }^{14}$

Learning Tools: which could help evidence based Practice also should be available in library.

\section{Examples include}

JAMA evidence ${ }^{15,16}$ It provides basic tools to understand and apply the medical literature and to make clinical diagnoses. It helps users to access the Rational Clinical Examination series and the 2008 edition of the User's Guide to the Medical Literature with additional teaching tools, such as two textbooks, education guides, glossary, calculators, worksheets, question wizards, weekly RSS feed of featured JAMA articles, compiled clinical scenarios, podcasts, and user-level customization features.

McMaster University: ${ }^{16}$ Resources for Evidence-Based Practice-Has excellent sections on "About EBP" and "Forming Questions." OSU does not have all the resources listed.

Evidence Based Practice ${ }^{16}-$ Available from Duke University (Free).

Pharmacists should be adequately equipped with knowledge of evidence based medicine. The practice should start from the student level, students of Pharm D and post graduate students of pharmacy practice branch in particular should have the knowledge of evidence based medicine. They can do literature research for the best evidence on a clinical question by consulting good database .They may answer clinical questions with accuracy. There are few free and subscription based databases are available listed in Table $8 .{ }^{17}$

\section{DISCUSSION}

Libraries are important in providing adequate information services to users of pharmacy colleges. The current situation of collections of pharmacy college libraries and feelings of library professional's about their job are analyzed. Adequate collections both print, non print and digital form exists in the library of pharmacy colleges. Library professional's are comfortable using online resources so it is easy for them to guide the students. There is insufficient manpower available in library both from technical as well as non technical side which is to be increased. This finding correlates with the finding of Mondal and Bandyopadhyay ${ }^{18}$. Increase in technical manpower will reduce the pressure on individual and increase in non technical manpower will be helpful in maintaining clean environment providing good drinking water and photocopying of material. All colleges must have one librarian, one assistant Librarian or deputy librarian and minimum of one library assistant. Most 
of the pharmacy colleges do have regular services but modern technology is not up to the mark in the libraries. Though many colleges started initiative works regarding digital libraries but they don't have services like Delnet, UGC Inflibnet and computerized bibliographic databases. The library professional's of all designations have high level of job satisfaction. This finding is supported by the research work carried out by Asadulla ${ }^{19}$ , he reported that in India, library professional with higher qualification was more satisfied with job than with less qualification. All participants in this study are highly qualified. The findings of the present study are limited in its scope in regard to sample size and regions. The study can be extended with huge number of sample including participants of different regions.

\section{CONCLUSION}

Academic libraries play a major role in pharmacy education in enhancing the knowledge of the students and faculty. Though the pharmacy college libraries do have adequate collection as a blend of print and non print forms, they are in lack of networked information services, security services and automation. The future libraries will have all these facilities. Library professional's must assist students and suggest to select, judge correct information and to opt for materials for selfpaced learning and programs that support new ways of teaching and delivering information resources. The academic library should be flexible, creative, and closely allied with the academic disciplines. The library professionals' participated in this study are satisfied with the collections and their job.

\section{CONFLICT OF INTEREST}

The Authors do not have any conflict of interest.

\section{ACKNOWLEDGEMENTS}

The authors are thankful to Mr. A. Madeswaran, Assistant Professor, College of Pharmacy, Sri Ramakrishna Institute of Paramedical Sciences, Coimbatore for his support in the research process.

\section{SUMMARY}

- Adequate collections both print, non print and digital form exists in the library of pharmacy colleges.

- There is insufficient manpower available in library both from technical as well as non technical side which is to be increased.

- Though many pharmacy colleges have regular services and started initiative works regarding digital library but they don't have services like Delnet, UGC Inflibnet and computerized bibliographic databases.

- The library professionals' of all designations have high level of job satisfaction.

\section{About Authors}

Irudayam Jayaraman is an Assistant Librarian in Anna University, Regional Centre, Coimbatore, Tamil Nadu. $\mathrm{He}$ is a Research scholar in Library and Information Science in Anna University, Tamil Nadu. He has 2 no. of journal paper (one accepted for publication); member in Indian Academic Library Association (IALA). His research interests include collection development, job satisfaction, library automation and digital library.

Dr. Tamizhchelvan Mottaiyachettiar, is an Deputy Librarian of Gandhigram Rural Institute, Deemed
University, Dindigul, Tamil Nadu. He has 28 articles in international journals and 19 articles in national journals and published 4 books. He has organised seven workshops and seminars, he has been a resource person, served as Chairperson and Rapporteur in the Technical Sessions. He is a life time member of Madras Library Association(MALA), Society for the advancement of Library Information Science(SALIS), Tamil Nadu Information Science and Foundation for information and communication.

\section{REFERENCES}

1. http://dictionary.reference.com/browse/education

2. John Shumaker W. The Higher education environment and the role of the academic library. ACRL Eleventh National Conference, April 10.13, 2003, Charlotte, North Carolina; 2003, Brophy P. The Library in the Twenty-first Century: new services for the information age. London: Library Association Publishing; 2001.

3. Suresh B, Ramesh M. Pharmacy Education and Practice in India-A Profession in Transition. International Clinical Pharmacist, Editor: Wafa Y. Dhadal 2010; 74(4): 1.

4. Brophy P. The Library in the Twenty-first Century: new services for the information age. London: Library Association Publishing; 2001.

5. Basak SC, Van Mil JW, Sathyanarayana D. The changing roles of pharmacists in community pharmacies: Perception of reality in India. Pharmacy World Science 2009; 31(6): 612-8.

6. Cetus. The Academic Library in the Information Age: changing roles. (Discussion Series). Consortium for Educational Technology for University Systems, California State University, City University of New York, State University of New York, Available from http://www.gvsu.edu/library/ librarylights/winter02/ChangingRoles.html; 1997.

7. Virkus S. Information Literacy and Learning. In: Libraries Without Walls 5 : the Distributed Delivery of Library and Information Services, eds. 2004 b. Brophy $\mathrm{P}$, Fisher $\mathrm{S}$ and J. Craven. Proceedings of an International Conference held on 19-23 September, organized by CERLIM, MMU. London: Facet Publishing; 2003. pp. 97-109. 
8. Ana Pavani MB. The role of digital libraries in higher education international conference on engineering education-ICEE, Coimbra, Portugal; 2007 September. 3-7.

9. George Kuh D, Robert Gonyea M. The role of the academic library in promoting student engagement in learning. College and Research Libraries 2003 July; 64(4): 256-72.

10. Suresh B. Pharma vision 2020: roles, responsibility and resources. Pharma Times 2006; 38(12): 13-21.

11. Kothari CR, Gaurav G. Measurement and scaling techniques. In: Research Methodology. India: New age International (P) limited publishers; 2004. 84-7.

12. https://statistics.laerd.com/spss-tutorials/kruskal-wallis-h-test-using-spssstatistics.php

13. www.bentham.org22.3.2013
14. The Ohio state university libraries, http://library.osu.edu/find/subjects/ pharmacy/drug- Information-sources/).

15. http://guides.mclibrary.duke.edu/ebm

16. http://library.osu.edu/find/subjects/pharmacy/evidence-based-pharmacyresources/

17. Suzanne A. Evidence-based medicine in pharmacy practice. US Pharmacist. 2009; 34(10): HS14-8.

18. Mondal AK and Bandyopadhyay AK. Application of ICT and Related Manpower Problems in the College Libraries of Burdwan. DESIDOC Journal of Library and nformation Technology 2010; 30(4): 44-52.

19. Asadullah, Esmail M, Nagarajan M. Job satisfaction among library professionals in Cuddalore and Vellore District. Journal of Advances in Library and Information Science 2012; 1(4): 173-6. 